\title{
ÖZEL ALAN / KAMUSAL ALAN DİKOTOMISİ: KADINLIĞIN "DOĞASI" VE KAMUSAL ALANDAN DIŞLANMIŞLIĞI
}

\section{Aysel GÜNINDİ ERSÖz*}

\section{ÖZET}

Kökeni eski Yunan düşüncesine dayanan kamusal/özel alan ayrımında polis, erkeğin, oikos ise kadının ve çocukların yeri olarak tanımlanmaktaydı. Ancak, kamusal/özel alandaki esas kopuş, Sanayi Devrimi ile birlikte olmuştur. Kamusal/özel ve üretim/yeniden üretim bölünmesi, geleneksel olarak bir işin cinsiyete göre bölünmesi bağlamında anlaşılmaktadır. Geleneksel bakış açısında, ev dışındaki ücretli iş, aynı zamanda onların "evin geçimini sağlayanlar" olarak kamusal statülerine has olarak erkeğin kamusal hayata katılımının bir parçası olarak algılanmıştır. Ekonomik açıdan bağımlı olan kimseler (kadınlar, çocuklar, özürlüler vb.) ise bu durumda ücretsiz ve özel alana aittir görüşü kabul görmüştür.

Türkiye'de özellikle, 1990'ı yıllarda kamusal alanın sınırları başörtülü kadınların kamuya ait yerlerde görünür olmak için gösterdikleri çabalar nedeniyle sıkça gündeme gelerek tartışılmıştır. 2002 yılında iktidara gelen AK Parti, 12 yıllık iktidarı sürecinde kadınların kamusal alanlara girmesi yönünde birçok karar almıştır.

Ancak, aynı iktidar partisi kadınları "anne", "eş" ve "ev kadını" gibi geleneksel rolleri içinde tanımlamakta ve muhafazakâr söylemleri de sıkça kullanmaktadır. Ayrıca, "en az üç çocuk", "kürtaj" ve "3 ve daha fazla çocuk sahibi kadınlara" erken emeklilik gibi vaatlerle kadınlar kamusal alanın dışında tutulmaya çalışılmaktadır.

Anahtar Kelimeler: Kamusal Alan, Özel Alan, Kadın, Dikotomiler, Yeniden Üretim, Başörtüsü.

*Yrd. Doç. Dr. Gazi Üniversitesi, Edebiyat Fakültesi, Sosyoloji Bölümü 


\title{
PRIVATE SPACE / PUBLIC SPACE DICHOTOMY: NATURE OF FEMININITY AND WOMEN'S EXCLUSION FROM PUBLIC SPACE
}

\begin{abstract}
In the distinction between public and private space whose base lies in the ancient Greek thought, polis was defined as the place of man, and oikos as the place of woman and children. However, the main division between public and private space has taken place with the Industrial Revolution. The division between public/private and production/reproduction is conventionally understood in terms of the division of labor in accordance with gender difference. From the traditional point of view, the paid work outside home has been perceived as a part of man's participation in public life which also contributes to their public status as 'the breadwinner of the house.' The view that those who are economically dependent (women, children, disabled etc.) belong to free and private space has been accepted in this case.
\end{abstract}

In Turkey, especially in the 1990s the borders of the public space have been on the agenda and discussed intensely due to the efforts of women wearing headscarves in order to be visible in public places. AK Party which became the ruling party in 2002, has made many decisions regarding women's entrance to the public space throughout their 12 year's government period. However, the same party has been defining women within their traditional roles such as 'mother', 'wife' and 'housewife' and frequently using the conservative discourse. In addition, with the promises such as 'at least 3 children', 'abortion' and 'early retirement for women with 3 or more children', an attempt to exclude women from the public space has also been made.

Key Words: Public Space, Private Space, Women, Dichotomies, Reproduction, Headscarf 


\section{GİRİs}

Tüm toplumlarda var olan kamu/özel, kültür/doğa, eril/ dişil, vb. temel sosyolojik ikiliklere cinsiyet bazında bakıldığında; erkek ilkler, kadın ise ikincilerle ilişkilendirilmektedir. Toplumlar, erkek ile kadın arasına bir hat çekerek kadınlara ve erkeklere farklı özellikler yükleyerek, onların farklı roller üstlenmesine ortam hazırlamaktadır. Üretim/yeniden üretim bölünmesi, geleneksel olarak bir işin cinsiyetlere göre bölünmesi anlamına da geldiğinden önemli sorunlara ve sonuçlara yol açmaktadır. Sosyalleşme sürecinde oluşan bu ayrışma kadın ve erkeğin daha sonraki hayatlarında hangi rollere yatkınlaşacağını, hangi rollerinin toplumca onaylanıp, hangilerinin onaylanmayacağının altını da çizmesi bakımından çok önemlidir. Genellikle, erkekle ilişkilendirilen özellikler olan "saldırganlık", "girişkenlik" gibi aktif roller onları iş dünyası ve politika hayatında daha etkin hale getirmektedir. Kadının "uysal" , "edilgen" ve "bağımlı" yapısı onun özel alana, çocuk bakımı ve yetiştiricilik rolüne itilmesine neden olmaktadır. Kadının "kadın alanı" olarak tanımlanan "hemşirelik", "çocuk doktorluğu" ve "sekreterlik" gibi alanlarda çalışması da "uysal" ve "yetiştirici" doğalarına bağlandığı için daha kolay kabul görmektedir.

En basit tanımı ile statü, toplumsal yapıda bireylerin durduğu "yeri" ifade eder. Özellikle geleneksel toplumlarda "evlilik" bir statü olarak "bekârlıktan" daha fazla değere sahipken, evrensel olarak tüm toplumlarda "dişilik" toplumsal bir değer olarak "erkeklikten" sonra gelmektedir. Bunun sonucu olarak; "erkek" ve "erkeklikle" ilişkilendirilen roller de daha fazla değer taşımaktadır. Örneğin; erkeklerle ilişkilendirilen kamusal alana daha fazla değer atfedilmekte, buna karşın "özel" alan ikincilliği ile öne çıkmaktadır. Kadının "doğası" çeşitli sosyal, kültürel, ekonomik, dinsel ve yasal nedenlere eklemlenerek kadın "özel" alan sınırları içinde tutulmaya çalışılmasına yol açmaktadır.

Günümüz Türkiye'sinde kadınlarla ilgili tartışmaların odak noktasında çoğunlukla "beden" bulunmaktadır. Kadınların bedenlerinin denetimi, hem aileyi koruyan/güçlendiren hem de kadınları 
aile içerisindeki eş ve annelik rolleriyle tanımlayan politikalar yoluyla sağlanmaktadır. Kadına ne kadar çocuk yapacağını söylemek, ister yasaklama isterse izin verme biçiminde olsun kadınların bedenlerinin devlet denetimine açılmasına işaret etmektedir. Bu nedenle siyasal iktidar kadınlardan evlerine kapanarak geleneksel rollerine razı olmalarını istemektedir. Bu yolla kadının, hem yoksulluk, hem de genel işsizlik sorunu ve dolayısıyla istihdam dışı kalan kadınların çalışma sorunu büyük ölçüde çözümlenmektedir (Sallan Gül,2014). Bu da kadınların kısa veya uzun süreli kamusal alanların dışında kalması anlamını taşımaktır. Kadın bedeninin bu merkezi konumu kitle iletişim araçlarına da yansımaktadır. Kadınlar medya da genellikle; annelik ideolojileri (ideal anne formuna uygun örnekler ya da çocuğunu terk eden anne örnekleri), örtünme pratikleri ile ya da şiddet mağduru olduklarında veya namus cinayetlerine kurban gittiklerinde yer alabilmektedirler.

Tüm toplumlar, kendilerini ve üyelerini yeniden üretmek ve bu yüzden de yeni insanlar üreten cinsel ve toplumsal ilişkileri barındırıp ayakta tutmak zorundadır. Cinsiyet düzeni ile ilgili tartışmalar çoğunlukla erkek ve kadının temel olarak birbirinden farklı olduğu iddiasıyla, yani konu hakkında daha fazla şey söylemenin olanaksız olduğu, bunun kanıtlanmasının da kendince gereksiz kıldığı bir önerme ile son bulmaktadır. Bu çalışma; kadınların kamusal alandan sürekli dışlandıkları / dışlanmaya çalışıldıkları ön kabulü ile yola çıkarak, özel alan/kamusal alan dikotomisini iktidarın "en az üç çocuk" ve "kürtaj" açıklamalarıyla ilişkilendirerek tartışmaktadır.

\section{I. ÖZEL/KAMUSAL KARŞITLIĞININ TARIHSEL KÖKLERİ}

Özel alan/kamusal alan ikiliğine tarihsel bir perspektiften bakıldığında bu ayrımın Antik Yunan dönemine kadar uzandığı ve biyolojinin erkek ve kadın arasındaki mevcut sosyal ayrımı meşrulaştırmanın ve erkeği iktidar sahibi olarak tutmanın bir yolu olarak günümüze kadar kullanılageldiğine tanık olunmaktadır. Bu nedenle, feministler 200 yıldır biyolojik cinsiyetlerinden dolayı yaşadıkları ayrımcılıkla mücadele etmektedirler. Bugün gelinen noktada "kadınlık" ve 
"erkeklik" kategorilerinin sosyal olarak inşa edildiği vurgulanırken, kadınlar "doğalarından" dolayı kamusal alandan dışlanmışlıkları ile mücadele etmekte ve bedenlerinin kendilerine ait olduğunu söylemektedirler.

Demokrasinin beşiği olarak kabul edilen Eski Yunan'da demokrasi tümüyle kadınların ve kölelerin dışarıda bırakıldığı bir sistemdir. Özgür kadınların vatandaş sayılmaması, kadınların kadın oldukları için kamusal alana girmeye ve yönetmeye elverişli olmadıkları varsayımı üzerine kurulmuştu. Kamusal/özel alan ayrımı eski Yunan düşüncesinde; polis (kamusal alan), ile oikos (hane) kavramlaştırmasından türetilmekte; polis; erkeklerin yönetim alanı, diğeri ise, kadınların ve çocukların yeri olan ev içi alan olarak görülmekteydi.

$\mathrm{Bu}$ antik kentlerdeki kadınların her türlü politik ve dinsel görevden mahrum edilip zanaat alanında dışlanması ile iletişim ağının da dışına itildiği belirtilmektedir. Polis özgürlüğün, kendi kaderini belirlemenin, dünyayı dönüştürmenin kamusal etkinliğin, insanın özne oluşunun alanı iken, oikos zorunluluğun, belirlenmişliğin alanıdır. Maddi üretim ve insanların yeniden üretimi köleler ve kadınlarca bu alanda sürdürülmüştür.

Ortaçağ'ın feodal toplumunda kamusal/özel alan ikiliği net değildir. Feodal toplum yapısında soylu aileler, hanedanlar arasında paylaşılan erkten bu ailelerin kadınları da bir ölçüye kadar yararlanmıştır. Ortaçağda, Hıristiyanlık inancı, kadını manastır yaşamında Tanrıya gönüllü hizmetkâr olarak sunmuştur. Yani, özel alan Hıristiyanlık ile saygınlık kazanmıştır. Diğer yandan Ortaçağda, kadınların bitkilerle şifa dağıtmaya yönelik eylemlerinin "büyü" olarak görülmesiyle kadınların toplu olarak yakıldıkları da bilinmektedir.

Antikiteden devralınan ekonominin siyasal ekonomiye dönüşmesi, değişen ilişkileri de yansıtıyordu. 17. yüzyıla kadar Oikos, despotun, pater familias'ın, ev sahibinin görev alanı içinde kalan "ekonomik" 
kavramının kendisi, ilk kez şimdi, karlılık yasalarına göre hesabı tutulabilen ticari işletmenin pratiğinde modern anlamını kazanıyordu: ev sahibinin görevleri, ev yönetiminde tutumluluk doğrultusunda sınırlanıyor veya artırılıyordu. Modern ekonomi artık Oikos'u odak almıyordu, evin yerini Pazar almışt1; ekonomi "ticaret bilimi"ne dönüştü (Habermas, 2010:82).

Polis ile oikos arasındaki ayrım, 17. yüzyıla gelindiğinde hukuksal düzenlemeye uygun olan alan (kamusal alan) ve hukuksal düzenlemeden azade olan alan (özel alan) olarak belirlenmiştir. Buna bağlı olarak, iki kişi arasında gerçekleştiği ve dış dünyaya kapalı olduğu kabul edilen aile içi ilişkilerin özel alan olduğu ve hukukun bu alana müdahale edemeyeceği uzun yıllar savunulmuştur. Bu durum eril devletçe kabul edilen ataerkil değerleri korumanın da bir yolu olmuştur.

Aynı şekilde, Aydınlanma düşünürleri de kamu/özel ayrımına giderek erkeği kamu, kadını ise özel alanla özdeşleştirmiştir. Yani, cinsiyete göre alan düzenlemesi yapmışlardır. Aydınlanma, Tanrı, hurafe ve doğa karşısında bilimin üstünlüğünü ve aklın zaferini kutlarken, kadın bedeni özellikle de "uterus" irrasyonelitenin (akıldış1lı) kaynağı olarak görülmüştür. Akıl çağının bu irrasyonalite korkusu, kadınların kamusal alandan dışlanmasının tek gerekçesi olmuştur (Entwiste, 2012:225). Aydınlanma çağının düşünürlerinden J. Locke, kadının erkek tarafından ikincilleştirilmesinin doğadan kaynaklandığını söylerken, Machievelli, kadının "duygusal" olduğu, Hobbes ise, kadının haklarını kontrat ile kocasına devrettiği için siyasette yer almadığını belirtir. J.J. Rousseau kamusal ve özel alanlarda erkek ve kadın ayrımını sosyal düzenin temel bir özelliği olarak görmektedir. Erkek "aklı" temsil etmekte ve onu kamusal alana uygun hale getiren ise onun "akıl yürütme" yeteneği olmaktadır. Buna karşın, kadın bedeni ile özdeştir ya da bedeni temsil eder. Kadının üreme sürecindeki bu rolü ise onun, özel ve ailevi alanda faaliyet göstermesinin nedenidir. Kadının özel alanla sınırlandırılması sosyal düzen için gerekli olduğu ileri sürülen "doğal hiyerarşinin" önemli bir kısmını oluşturmaktadır. Kadının kamusal alana girişi öne sürülen bu doğal hiyerarşinin bozulması ve sosyal düzenin ortadan 
kalkmasına neden olmaktadır. Rousseau aklın gelişiminin sadece erkeklerde mümkün ve istendik olduğunu iddia etmiştir. Görülüyor ki, aydınlanma çağı insan aklını öne çıkarırken henüz kadının aklını rasyonelleşme sürecine dahil etmemiştir. Aralarında Durkheim, Weber ve Spencer'ın da bulunduğu geleneksel sosyoloji teorisyenleri de sosyoloji olarak betimledikleri ve açıkça öncülüğünü yaptıkları şeyin içinde, eleştirel bir şekilde değil alışılagelmiş bir şekilde karşıladıkları toplumsal cinsiyet konusunu önemsizleştirerek, etraflarında dolaşan feminist iddialara temelde muhafazakar tepkiler göstermişlerdir (Ritzer, 2008:7). Örneğin; Durkheim kadının toplumsal konumu ve kimliğinin esasen üreme ve çocuk yetiştirmeye katılımıyla şekillendirildiğini varsayıyordu (Giddens, 2008:147). "İntihar" adlı çalışmasında ise, cinsiyetin intihar ve adam öldürme üzerindeki etkisini açıklamaya yöneldiğinde cinsiyetin etkisinin organik nedenlerden çok daha fazla toplumsal nedenlerde aranması gerektiğine vurgu yapıyordu (Durkheim, 1992:353).

Davidoffa (2002:150) göre, kadınların doğaya erkeklerden daha yakın olduklarının düşünülmesinin temel nedeni fizyolojik süreçler (adet görme, çocuk doğurma, emzirme) ve bunların uzunluğudur. Ayrıca kadınlar, toplumun içine alacağı, yeni konumu belirsiz bireyler doğurmaktadır. Onlar genellikle küçük çocukların bakımıyla görevlendirildiklerinden yaşamlarının daha büyük bir bölümünü toplumsallaşmamış ve bundan dolayı "medeniyetleşmemiş" güçlerle geçirirler. Erkekler ise "kişi” olarak görülmektedir. Bu nedenle kadınların konumu, erkek olmayan toplumun kültüründe belli bir rolü olan, ama erkeklerle aynı derecede bilinçli varlıklar olmamalarından dolayı muğlâktır denilmektedir.

Habermas (2010:175) Batı'da 18. yüzyıldan beri oluşan kamusal alanın tarihçesini "Kamusallığın Yapısal Dönüşümü" adlı çalışmasında ele almaktadır. Kamusal alanın tarih içindeki dönüşümlerini takip ederek feodalizmde önce "temsili kamu", sonrasında "edebi kamu" daha sonrasında ise "politik kamunun" oluştuğunu ifade etmektedir. "Kamusallık ancak, ekonomik ve toplumsal koşullar herkese 
eşit imkân tanıdıkları takdirde güvence altına alınmış olur” görüşündedir. Böylece ekonomik gücü olmayanlar ve kadınlar mülk sahibi olamadıkları ve eğitim imkânlarına ulaşamadıkları için kamusal alandan dışlanmaktadırlar.

Bundan başka, Özel / Kamusal dikotomisinin modern kuruluşunda, daha keskin bir ayrımlaşma sanayi devrimi ile birlikte yaşanmıştır. Eril kamu ve dişil aile-hane-özel alan ayrımı modern endüstriyel kapitalist toplumsallığın ruhunu oluşturmuştur (Sancar, 2009:51). Sanayi devrimi ile birlikte malların üretimi haneden çıkıp, önce atölyelere sonra da fabrikalara kaymış, böylece çalışma-üretim alanı ile ev/hane iki ayrı alan haline gelmiştir. Modern anlamda “özel alan”ın oluşmasının ev/işyeri ayrışmasıyla doğrudan bağlantılı olduğu görülmektedir. Bu durum ekonomik, kurumsal, ideolojik ve giderek politik bir ayrım olarak "piyasa" ve "hane"nin birbirinden farklı cinsiyet düzenleri oluşturması sonucunu getirmiştir. Kendi aralarında hiyerarşik öncelikler-üstünlükler de içeren bu tür "cinsiyetlendirilmiş" mekân'ın oluşumu da modern toplumsallaşmanın özelliği haline gelmiştir (Sancar, 2009:53-54).

Kamusal/özel alan ayrımının ücretli ve ücretsiz iş arasındaki ayrıma karşılık geldiğini düşünenlerin aksine Slater (2012:207) kamu / özel alan ayrımının ücretli / ücretsiz iş arasındaki ayrımdan daha fazla anlamlarla yüklü olduğunu söylemektedir. O ailenin özel alanı, romantik çiftlerin özel/mahrem dünyasında olduğu gibi, her şeyden önce kadının erkekle ilgilenmesi ve çocuk dünyaya getirmesiyle yani yeniden üretim işlevini kadının "doğallığı" ile ilişkilendirmektedir. Kamu alanı ise erkeğin "doğal" akıl, üretim ve öz farkındalık kapasitesini yansıtmaktadır. Akıl / his, rekabet / sevgi, üretim / yetiştirme, araçsal akıl / değerler, maddi veya parasal bağlar / kişisel bağlarla ilişkili dikotomilere bakıldığında kamusal alan birincilerle örtüşürken, ikincilerin doğrudan özel alanla bağlantılı olduğu görülmektedir. 
Sosyolojik kuramlar içinde önemli bir yeri bulunan işlevselci kuramın en tanıdık temsilcisi Parsons ise araçsal ve dışavurumsal rol ayrımlaşmasını toplumsal sistemin devamı için gerekli görmüştür. Neden erkeklerin araçsal, kadınlarınsa dışavurumsal rollerden sorumlu olduğu ve niçin bu rollerin farklı biçimler aldığı sorusunu cevaplayan Parsons rol farklılaşmasını Freud'un psikanalizinden etkilenerek biyolojik bir indirgemecilikle, biyolojik cinsiyet ile yani; kadının çocuk doğurması ve çocuğun bakımı sırasında anne-çocuk arasında kurulan güçlü bağla açıklamaktadır. Ona göre erkeğin çocukları ile bu türden bir ilişkisi olmadığı için koca araçsal rollerden sorumludur. Bu nedenle Parsons, kadının çocuk doğurması ve çocuğun bakımından birinci derecede sorumlu olmasının kadının dışavurumsal rollerde uzmanlaşmasının yeter koşulu olduğunu düşünmektedir (Parsons ve Bales, 1955:23). Parsons'a göre bu araçsal, dışavurumsal rol farklılaşması sistemi korumaktadır.

Kamusal / özel ayrımı mahrem / namahrem, ücretli ve ücretsiz gibi farklı ayrımları barındıran ve aslında geçmişi köklü bir ataerkil zihniyete dayanan bir ilişki durumudur. Erkek üstünlüğü ve egemenliğinin nasıl inşa edildiğini ve bunun kurumlarını göstermesi bağlamında ataerkillik kavramı diğer birçok tartışmada olduğu gibi özel alan / kamusal alan ayrımlaşmasında da anahtar rol üstlenmektedir. Çünkü kadınların kamusal alanın dışına itilmelerinin nedeni doğrudan ataerkil ideolojinin doğa - kültür ayrımından kaynaklanmaktadır. Kadınların doğurganlık özellikleri sebebiyle bedenleri doğa ile özdeşleşmiş̧tir. Buna karşıllk, erkeklerin, uygarlığı ve kültürü temsil ettiği kabul edilmektedir. Böylece, erkeklerin işi kültür ve uygarlık yaratmak, kamusal alanda otorite kullanmak ve yönetmek, yani siyaset yapmak; kadınlarınki ise ev ve aile içinde kalıp çocuk doğurmak olarak belirlenmiştir. Çıkış felsefesi “insanlar eşittir” olan liberalizmde bile geleneksel olarak sesleri en fazla duyulanlar ve etkili olanlar erkeklerdir. Bugün hala devam eden bu durum, pratikte olduğu kadar, hukuk sisteminde de kendini göstermektedir. Toplumsal cinsiyet, yani biyolojik cinsiyetin toplumsal 
ve kültürel kurgulanışı (ya da başka bir deyişle, tarihsel ve toplumsal olarak var olan cinsiyet kalıpları ve rolleri), kadınların herhangi bir alandan dışlanmaları için gerekçe olabilmektedir.

Kadının "doğası" onun kamusal alandan dışlanması için yeter mi? sorusuna belki de en doyurucu cevap antropolog ve bir feminist olarak Margaret Mead'ten gelmiştir. Mead Üç Yeni Gine kabilesini inceleyerek cinsiyet ve toplumsal cinsiyetin evrensel düzeyde birbirine tekabül etmediğini "erkek" ve "kadın" biyolojik kategorileri ile "erkeklik" ve "kadınlık" kültürel özellikleri arasında hiç bir "doğal" bağın bulunmadığını ortaya koyarak göstermiştir (Entwistle, 2012:218).

Alanların cinsiyetlere denk gelmesi yani kamusal-erkek/özel-kadın ayrışması kadının toplumsal yaşama katılımında da belirleyici bir rol oynamıştır. Kamusal/hane karşıtlığındaki açık olmayan yönler kadınlar için pratikte ciddi sorunlar doğuran ataerkil uygulamalara neden olmuştur. Böylece erkekler ekonomik ve siyasal alanla yani kamusal alanla ilgili iken, kadınlar yeniden üretim süreciyle, ev içi etkinliklerle sorumlu tutulmuşlardır. Kadınların devlete ve kamusal alana katılmaları çoğu kez kısıtlanmış ve bu kısıtlama "kadınların doğaları" ile açıklanmıştır. Bu nedenle, 18. yüzyıldan itibaren kadınlar da, erkekler gibi, birey ve yurttaş olmayı talep etmeye başlamışlardır. Bu nedenle, Liberal feminizmin esas hedefi, kadınların "kamusal" alana girmesini önleyen ve onları eve hapseden yasaları ve uygulamaları ortadan kaldırmaya yönelik olmuştur.

1789 Fransız ihtilalı "Eşitlik, Özgürlük ve Kardeşlik" talepleri ile yapılmış, ancak başlangıçta olmasa da sonunda kadınları dışlamıştır. Nitekim Berktay (2011:122) Fransız ihtilalindeki kadınların ihtilalden nasıl elleri boş döndüklerini hatırlatmaktadır. Fransız ihtilalinde kadınlar, heyecanla, erkeklerin yükselttiği “eşitlik, özgürlük ve kardeşlik” bayrağının peşine düşmüş, ama "kardeşliğin" “erkek kardeşliğì” (“fraternite”, "brotherhood”) olduğunu, hayal kırıklığı içinde pek çabuk anlamışlar, "hak, özgürlük ve adalet" istemiyle gerçekleştirilen ihtilal bir süre sonra kadınları dışlamıştır. 
Bireyin özgürlüğünü, özerkliğini, temel haklarını garanti altına almayı amaçlayan ve bu nedenle siyasal iktidarın sınırlandırılması üzerinde duran bir düşünce akımı olarak Liberalizm, kadınların hak taleplerinin ve kamusal alana katılmayışlarının sorgulamasına yol açmıştır. 18. yüzyıl liberal feministleri içinde en bilinen isimlerden olan Mary Wollstonecraft "A Vindication of Rights of Women" (Kadın Haklarının Bir Savunusu) adlı çok bilinen eserinde; önemli işlerin aklın geçerli olduğu kamusal alanda yapılırken, önemsiz hazların kadınlar ile ilişkilendirilmesine ve özel alan ile sınırlandırılmalarına karşı çıkarak, bunun hem kadınların itibarını zedelediğini hem de kadınların akıllarını ve eleştirel yeteneklerini geliştirmelerini engellediğini savunmuştur. Ona göre akıl her insanda aynıdır (Ecevit, 2011:13).

Yine liberal düşüncenin önemli bir temsilcisi olan John Stuart Mill'de, kadınların bağımlılık konumlarını sürdürmelerinin nedeninin, geleneksel kadınlık rolünün devamından öte, erkeklerin onları orada tutma isteği olduğunu belirtir. Ona göre kadınların kamusal alanın dışında tutulmaları "erkek cinsinin çoğunluğunun henüz eşitleri olan bir kadın ile birlikte yaşama düşüncesine tahammül edememeleri ve bundan dolayı kadınların ev hayatındaki ikincil konumlarını sürdürme isteği olduğunu ifade etmektedir (Akt. Ecevit, 2011:13). Kamusal/özel alan ayrımının cinsiyetçi niteliğinin "doğaya" gönderme yapılarak meşrulaştırılmasına karşı çıkmıştır. Bu nedenle 1848 - 1920 dönemini kapsayan birinci dalga feministler başta seçme / seçilme hakkı olmak üzere eşit işe eşit ücret, her iş alanında çalışma hakkı, eğitim hakkı, yasal reform (özellikle aile hukuku - evlilik, boşanma, vs.) hakları için mücadele etmişler.

İki Dünya savaşı yaşanan 20. yüzyıl kadınların seslerini duyurmaları ve haklarını elde etmeleri açısından önemli bir yüzyıl olmuştur. 20. yüzyılın ortalarında kurulan Birleşmiş Milletlerce, 1945 yılında kabul edilen ilk uluslararası yasal doküman olan "İnsan Hakları Evrensel Beyannamesi"nde yer alan "cinsiyete dayalı ayrımcılık yapılmaması" ilkesinin getirilmesi önemli bir kazanım olmuştur. 
Ayrıca, 1946 yılında; kadın-erkek eşitliği ilkesinin uygulanmasını sağlamak amacıyla Kadının Statüsü Komisyonu (KSK) kurulmuştur (Kadının Statüsü Genel Müdürlüğü, 2014).

1975 yılı Birleşmiş Milletler tarafından Uluslararası Kadın yılı olarak belirlenmiştir. Aynı yıl I. Dünya Kadın Konferansı Mexico City’de gerçekleştirilmiştir. Konferansta toplumsal cinsiyet eşitliğinin tam olarak sağlanması ve ayrımcılığın önlenmesi, kadının kalkınmaya katılımı ve entegrasyonu, dünya barışının sağlamlaştırılmasına kadınların katkısının artırılması konuları üzerinde durulmuştur. Bunu takiben, Birleşmiş Milletler tarafından 1976 - 1985 yılları arası "Kadın On Yılı" olarak ilan edilmiş ve 1980 yılında Kopenhag'da düzenlenen II. Dünya Kadın Konferansında ilk beş yılda kaydedilen gelişmeler değerlendirilmiştir. Kadın konferanslarının üçüncüsü 1985 tarihlerinde Nairobi'de 157 ülkenin katılımı ile yapılmış ve Konferansta "Kadının İlerlemesi İçin Nairobi İleriye Dönük Stratejileri” kabul edilmiştir. IV. Dünya Kadın Konferansı ise, 1995 yılında Çin / Pekin'de gerçekleştirilmiş ve kadının özel ve kamusal alana tam ve eşit katılımı önündeki engellerin, kadınların ekonomik, sosyal, kültürel ve politik karar alma pozisyonlarında ve mekanizmalarında yer almaları yoluyla ortadan kaldırılabileceğini hatırlatılarak, hükümetler önlemler almakla yükümlü kılınmıştır (KSGM, 2014).

Yine, BM Genel Kurulu tarafından 1979 yılında Kadınlara Karşı Her Türlü Ayrımcılığın Önlenmesi Sözleşmesi (CEDAW) kabul edilmiştir. Sözleşme kadınlara karşı ayrımcılığı önlemek için var olan yasal ve bağlayıcı doküman olma özelliği taşımakta kamusal alan/özel alan karşıtlığı ile mücadele etmektedir (KSGM, 2014).

\section{21. YÜZYIL TÜRKİYESİNDE KADININ "DOĞASI" SÖYLEMI}

Habermas kamusal alanı, "özel şahısların, kendilerini ilgilendiren ortak bir mesele etrafında akıl yürüttükleri, rasyonel bir tartışma içine girdikleri ve bu tartışmanın neticesinde o mesele hakkında ortak kanaati, kamuoyunu oluşturdukları araç, süreç ve mekânların tanımladığı hayat alanı" olarak 
tanımlar. $\mathrm{Bu}$ tanıma bakılarak kamusal alanın kamuoyunu oluşturan alan olduğu sonucuna varılabilmektedir. Osmanlıdan günümüze Türk toplumunda kamusal alana ilişkin tartışmaların iki noktada ilerlediği görülmektedir. Bunlardan birincisine göre, Osmanlı imparatorluğunda burjuva sınıfının olmayışı ve basının 1860'lara kadar gelişmemiş olması kamusal kavramını ortaya çıkarmamıştır. Bunun karşısında yer alan görüşlere göre ise, özel alan ile devlet arasında ve devlete karşıtlık biçiminde bir ara formun, 16. yüzyılın ortalarından itibaren Osmanlı imparatorluğunda oluştuğu, Yeniçeriler ve yönetilen konumundaki diğer toplum kesimlerinin amaç-yönelimli eylemlerle devlete karşı güç blokları haline gelmeleri ile karagöz ve meddahlık gibi tiyatro performanslarının varlığı Batılı anlamda olmasa bile kamusal alanın dinamiklerinin Osmanlı'da var olduğu şeklinde yorumlanmaktadır (Ercins, 2013:305).

Cumhuriyet yönetimi ise, kamusal alanı kendi eliyle kurmuş; bu alanı toplumun ortak meseleleri hakkında bireylerin rasyonel ve eleştirel tartışma yaptığı bir alan olarak değil, modernist pratiklerin ve yaşam biçimlerinin uygulandığı bir alan olarak görmüştür. Bu oluşum da, Türkiye'de genellikle kamusal alan deyince akla, devlete ait devlet idaresi, organları, kuruluşları, görevlileri ya da etkinlikleri gibi şeylerin anlaşılmasına yol açmıştır.

Cumhuriyetin kurulması ile birlikte kadın kamusal alanda tanımlanmaya, tebaadan yurttaşlı̆ga, aile yaşamında ise eşit haklara sahip bir eşe dönüşmeye başlamıştır. 1926 y1lında kabul edilen medeni kanunla birlikte kadınlar yasal hakları konusunda çok önemli kazanımlar elde etmiştir. Cumhuriyet'in resmi ideolojisi kadının kamusal alana çıkmasından ve meslek sahibi olmasından yanadır. Ancak, dönemin kadın konusundaki algılamasına biraz daha yakından bakıldığında, gelenekselci kalıp ile modernleşmeci kalıp arasında, toplumsal cinsiyet rolleri açısından temel bir farklılık olmadığı görülmektedir. Batıcı model, kadına özel alandaki "doğal görev" ve sorumluluklarının yanı sıra, toplumsal alanda da fedakârlık ve sorumluluk yüklemektedir. Bu durum, kadınları "çifte yük”le karş1 
karşıya bırakmış, rol çatışmalarına neden olmuştur (Berktay, 2006:109). Hatta "yurttaş anne" örneğinde olduğu gibi bu rollere kamusal anlamlar yüklendiği tartışılmıştır (Acar-Savran,2009:99).

$\mathrm{Bu}$ görüşü destekleyen Arat (http://www.halkevleri.org.tr/) Cumhuriyet döneminin başlarında, Devletin elit tabakadan bir grup kadının kamusal hayata daha fazla girmesini desteklenirken, sayıları gittikçe artan "öteki" kadınlara farklı bir mesaj iletildiğini savunmaktadır. "Öteki" kadınlardan daha çok özel alanda kalarak, yuva kurma sürecindeki rolleri ile modernleşme sürecine katkıda bulunmaları beklenilmiştir.

Türkiye'de kadınların modernleşme projesinin inşasındaki rollerine baktığımızda modernleşmeci devletin kendi çıkarlarına aykırı gördüğü anda kadınların eylemlerini nasıl dizginleyebildiği iki örnekle aktarılmaktadır. 1923'te Kadınlar Halk Fırkasının kuruluşuna yönelik çalışmaların basında yol açtığı farklı yorumları ve "fırka" sözcügüne özellikle erkeklerce gösterilen direncinin altı çizilmektedir. Toplumu cinsiyet esasına göre bölen bir firkanın günün koşullarına uygun düşmeyeceğine erkeklerce karar verilmiştir. Müstakbel bir kadın partisinin kısa bir süre sonra kurulacak olan Cumhuriyet Halk Fırkasına ilgiyi azaltabileceği öne sürülerek, Kadınlara parti yerine Cemiyet kurmaları önerilmiştir. Böyle bir talimatla kurulan Türk Kadınlar Birliği de Kadınlar Halk Fıkrası ile aynı sonu paylaşmaktan kurtulamaz. Birlik, 1935 'te Türkiye'de bir Feminizm Kongresi'ne ev sahipliği yapmak üzere dünyanın çeşitli yerlerindeki feministlerle işbirliğine girip, yükselen Nazi tehdidine karşı bir bildiri yayınlayınca, eril zihniyet bundan da hoşlanmamış ve uygun bir gerekçeyle birliği kapatmıştır (Akt. http://www.halkevleri.org.tr/).

Ancak, Türkiye'de esas kamusal/ özel karşıtlığı ve buna ilişkin tartışmalar, 1980'li yıllarla birlikte alevlenmiş, örtünme pratikleri nedeniyle kadınlar bu tartışmanın başkahramanları olmuşlardır. Nilüfer Göle'ye (http://www.siviltoplum.com.tr/) göre bu tartışmanın dozunu artıran Müslüman kadının türbanıyla kamusal alana çıkma talepleri yani sosyolojik anlamda toplumsal aktör olma biçimleriydi 
ve bu yolla 20 yıldır devam eden İslâmcı hareketlerle kamusal alanın sınırları dışa vurulmuştu. Kamusal/özel karşıtlığı ve kadınların kamusal alanda yer almak istemeleri konusundaki tartışmalar iki temel noktada gelişmiştir. Taraflardan birisi örtünmenin özel alan ile kamusal alan arasındaki sınırı belirleyip simgeleştirdiği ve bunun da ötesinde siyasal İslâm'ın kadınları örterek, yani örtü yoluyla denetleyerek (de olsa) kamusal alana çıkartmak gibi bir misyonu yüklendiği savunuldu. Bunun yanı sıra, modernitenin özel alanla kamusal alan arasında tanımladığı geçişlilik/geçişsizliğin örtülü kadınlarca yeniden tanımlandığı ileri sürüldü. Bunlara karşılık, tesettürün kadınları toplumdan, kamusal alandan soyutladığı da iddia edildi (Acar-Savran, 2009:98-99). Türkiye'de kadınların özellikle eğitim kurumlarına girişlerinin önünde baş örtme pratikleri ciddi bir engel teşkil etmiş, kadınlar kamusal alana girmek, devlet ise kadınları "özel" alanda tutmak için yıllarca mücadele vermiştir. Kamusal alanın sınırları uzun yııllar boyunca tartışılmıştır.

"İslamcı" olarak adlandırılan kadınların kamusal alana çıkma konusunda yaşadıkları isteklilik ve mücadeleleri konusunda onca şey yazılmıştır. Nitekim AK Parti'nin iktidar olmasında bu kadınların örtünerek kamusal alanda var olmak için giriştiği mücadelenin etkisi büyük olmuştur. Bu nedenle, 2000'li yıllarla birlikte özellikle başörtüsü nedeniyle kamusal alan dışında tutulan ve bunu başta eğitim hakları olmak üzere birçok haklarının gasp edilmesi anlamına geldiğini söyleyen ve bu eşitsizliği ortadan kaldırmak isteyen kadınlar önce AK Partiyi iktidara taşımış, bu iktidar ile de kadınların kamusal alanlardaki görünürlüğü artmıştır. Ben kamusallığı dar anlamından yani devlete özdeş ve devlete ait binalardan çıkarıp, Arendt'ten ödünç alarak "açık, görülebilir, kolektif ve herkesin rahatlıkla girebildiğị" yer anlamında, dolayısıyla daha geniş anlamda kullanmak istiyorum. Bu kapsamda; en geniş anlamıyla eğitim kurumları, tiyatro ve sinema salonları, sergi salonları, sivil toplum örgütleri, kermesler, alış veriş merkezleri, cafeler, oteller, lüks tatil köyleri, trafik, her türlü kurslar yani kadınların diğer insanlarla birlikte olduğu, "sosyalleşebildiği" her yeri kamusal alan olarak 
tanımlıyorum. Daha önce başörtüsü ile kamusal alana çıkmasına izin verilmeyen kadınların bu bastırılmışlığın bir yansıması olarak "kamusal alanda yer almalarında gözle görülür bir artış deyim yerinde ise tam bir patlama yaşanmaktadır. İşte tam da, bu ortamda iktidarı elinde bulunduranlar kadınlara doğalarını hatırlatma gereği duymuşlardır. Eski Başbakan Recep Tayyip Erdoğan sık sık nikâhlara katılarak çekirdek aileyi kutsarken, "en az üç çocuk" beklentisini yeni evli çiftlere ileterek, onlara önemli bir misyon yüklemektedir. Diğer yandan, başörtülü kadınların uzun hak mücadelelerinin gereğini yapan iktidar, başta TBMM olmak üzere devlete ait kurumlarda kadınlara başörtülü çalışabilmenin yolu açmıştır. Ancak, iktidar partisinin söylemleri ile kararları arasında bir tutarsızlık bulunmakta, iktidar partisi bir yandan kadınları kamusal alana taşımak istekliği gösterirken, diğer yandan da kadınlara asli görevlerini hatırlatmakta ve bu yolla kadınları özel alanda tutmaya çalışmaktadır.

2002 yılından sonra uygulanmaya başlanılan neoliberal-muhafazakâr hegemonya kadınların bedeni üzerindeki denetimi olgunlaştırmaktadır. $\mathrm{Bu}$, ailenin sosyal politika aracı haline getirilmesi ve kadınların aile içerisinden tanımlanarak "kutsal aile" ve "kutsal annelik" söylemiyle meşrulaştırılmaktadır. Kadınlardan ekonominin gereksinim duyduğu "genç ve dinamik nüfusun üreticisi” rolünü benimsemeleri beklenilmektedir (Kubilay, 2014:397). Bu yaklaşım "En az üç çocuk", "kürtaj" ve çalışmaları devam eden "3 ve daha fazla çocuk doğuran kadına erken emeklilik" hakkı verilmesi konusundaki vaatler ve söylemlerle somutlaşmaktadır. En az üç çocuk talebinin dile getirildiği her konuşmada görülen "güçlü ekonomi, güçlü Türkiye" vurgusu, kadınların bedenlerinin denetimiyle, daha doğrusu kadınların rahimlerinin bir kez daha devlete ait kılınmasıyla sonuçlanmaktadır (Kubilay,2014:397). Bu söylemler ve vaatlerin uygulanmasıyla ise kadınlar uzun/kısa süreli kamusal alanın sınırları dışında tutulabilecektir. 
Yüzyıllardır eril bakış açısı kadını özel alana hapsetmenin bir yöntemi olarak kullanılmış kadınlara yeniden üretim sürecindeki işlevleri hatırlatılmıştır. Ne zaman kadınlar kamusal alanda daha fazla yer almaya başlasa bir şekilde kadınların önü kesilmekte ve "doğaları" hatırlatılmaktadır. Bu ataerkil iktidarın kurumsallaşmasında temel rolü bulunan Devlet tarafindan sıklıkla yapılmaktadır. Binlerce yıllık geçmişi olan ve iyice derinlere kök salmış bulunan ataerkillik ve buna bağlı cinsiyetçilik gibi kültürel geleneklerin değişmesine yönelik güçlü direnç oluşmuş, eril zihniyet, eril devlet kadına yönelik düzenlemelerde bu cinsiyetçi yönünü muhafaza etmiştir. Türkiye'de devletin özel alana ilişkin neleri düzenlediğine baktığımız zaman bu daha iyi anlaşılabilmektedir. 1990'lı yılların başına kadar "kadının çalışmasının kocasının iznine bağlı olduğu ve "aile reisliğinin" yasalarla düzenlendiği görülmektedir. Yine, 765 sayılı eski Ceza Yasası'nın 438. maddesinde "Irza geçmek ve kaçırmak fiilleri fuhuşu kendine meslek edinen bir kadın hakkında irtikâp olunmuş ise, ait olduğu maddelerde yazılı cezaların üçte ikisine kadarı indirilir" şeklindeki ifade kadına yönelik cinsel suçların nasıl bir ayrımcılık içerdiğini göstermesi bakımından önemlidir. Devletin yaptığı bu düzenlemelerine karşın, 1998 y1lına kadar aile içindeki şiddet devlet tarafından görmezden gelinerek buna ilişkin herhangi bir düzenleme yapılmamıştır. 1998 yılında çıkarılan ve 2012'de revize edilen aile içindeki şiddeti önleme yasası ise uygulamada eril zihniyet örüntülerine takılmıştır. Yine, kadına yönelik tek resmi örgütlenme olan ve kadınların sorunlarına çözüm üretmek amacıyla kurulan o zamanki adıyla "Kadının Statüsü ve Sorunları Genel Müdürlüğü" 10 yıl yasal dayanaktan mahrum bırakılmıştır. Kadına yönelik birçok düzenleme ise ya Avrupa Birliğine uyum süreci ya da kadın örgütlerinin yoğun baskıları sonucunda zorlukla hayata geçirilebilmiştir.

Son söz olarak, 21. yüzyıl Türkiye'sine iktidarı elinde tutanların söylemleri üzerinden baktığımızda bir cinsiyetin doğaya yakınlığı temelinde özel/ kamu ayrımında çok da yol kat etmediğimiz anlaşılmaktadır. Kadınlar doğal ve bedeni özellikleri dolayısıyla çocuk doğurma ve yetiştirmeleri 
nedeniyle kamusal alandan dışlanmaya, özel alanla sınırlandırılmaya çalışılmaktadırlar. Nitekim tarihe baktığımızda buna kanıtlar bulmakta zorluk çekilmemektedir. Bu, kadınların 200 yıldır devam eden "eşit bireyler olma" taleplerine "kör" kalınarak kadınların yok sayılması anlamına gelmektedir. Kadına biçilen rolü "ev kadınlı̆̆ı", "anne" ve "eş rolü" ile sınırlayan, kadını sadece aile içinde gören ve görmek isteyen, bunu kültür yoluyla kuşaktan kuşağa aktaran ataerkil anlayış eril iktidar yolluyla dışa vurulmaktadır. Böylece kadınlar bedenleri ile özdeşleştirilerek, adeta kimliksizleştirilmektedirler. Kadınların uygun olan her vesile ile kamusal alandan dışlanarak özel alana hapsedilmesi ise para ve mülkle birlikte gelen güç ve bağımsızlı̆̆a, statü ve eşitliğe sahip olma haklarının gasp edilmesi anlamına gelmektedir. Diğer yandan, kadınların özel alanla sınırlandırılması ise kadınların denetlenmesini kolaylaştırmakta, kadını erkeğe tabi kılarak kadının erkeğin mülkü olarak görülmesine neden olmaktadır. Bu nedenle Feminist hareketin seçkinci - tahakkümcü tavrına karşı çıkarak, Müslüman kadınların inançlarıyla bir kadın olarak ezilmeyi reddedişleri arasında bir çelişki olmadığını göstermeye çalışan kadınlara bu konuda da önemli görevler düştüğü düşünülmektedir. 


\section{SUMMARY}

According to the biological view, one of the theoretical approaches which is related to the explanation of gender inequality, in the origin of the disparity between men and women the biological differences of males and females lie, that is chromosomes, hormones, brain sizes and inherited characteristics exist. Again, according to these theories, the fundamental role of women in the process of reproduction, which is to be responsible for child feeding and care at first degree, has resulted in her being limited to private space. In contrast, the production function, that is bringing home the bread has been left to man's responsibility. While the private space is accepted as the place of freedom, subjectivity, inequality, natural feelings, love and partisanship, the public space has become the world of universality, independence, equality, and impartiality. When gender is sociologically looked at as a given status, it is seen that woman's status is lower than man. Therefore, the items production, public area, logic, and culture associated to men are more valuable than reproduction, private space, emotions and nature.

In ancient Greek thought the distinction between public and private space was derived from the conceptualization of polis (public space) and oikos (household); polis was consisting of the area of men's governance and the other the domestic area which was considered the area of women and children. Having reached to the 17th century, it has been seen that the dual structure has been kept as the public space which was suitable to legal regulation and the private space which was free from any legal arrangements. However, the primary distinction between the dichotomy private and public space has gained a meaning with the Industrial Revolution, and with a sharp differentiation, work/production space and home/household space have become two distinct areas. While men were going to public places to fulfil their role in production, women went on staying in private space. 
Defining public area is quite difficult and many different definitions are found. While talking about public space, one of the prominent names springing up the mind is Habermas. Habermas defines the public space as "the living space defined by tools, processes and places where individuals reason around a common issue relating themselves, get in a rational discussion, form a common view, public opinion as a result of this discussion." Another thinker Hanna Arent tends to see public space as the area of active citizenship and policy.

When this concept is investigated in terms of Turkey, the concept public space has mostly been used to describe the institutions belonging to government; however, in the discussions taking place in recent periods it is seen that the borders of public space, excluding them from the state owned institutions, could be expanded. For example, Aksit (2010:183) says that in Turkey female publicity has been experienced in different places and hence the borders of publicity have expanded.

Nilufer Gole, who conceptualizes private space as 'confidential', associates this term with something concerning the hidden area, secrecy, family life, woman's space and forbidden thing to the foreigner's glances. The 1990s were the time in which the debates relating the public/private space dichotomy was frequently being discussed in Turkey. The efforts of women putting on headscarves to enter into the public institutions belonging to the state and hence to become visible with their headscarves have increased the intensity of the discussions. While the ruling party, on one hand, is making legal regulations allowing women with headscarves to enter into the public space, on the other hand with the discourses such as "at least 3 children", "abortion" and "early retirement opportunity for women with 3 or more children", it reminds women their role in reproduction and tries to exclude them from public space or keep women at certain dimensions of public life. Women having feminist identity have revolted against masculine government's intervention to their body with the slogan "our body belongs to us", working heartily and wandering from door to door. Whereas, this manly oriented perspective 
is one of the biggest obstacles preventing women from joining social life and realising their individualisation through these means, a pledge is put in women's future. 


\section{KAYNAKÇA}

Acar-Savran, G. (2009). Beden Emek Tarih. İstanbul: Kanat kitap

Akşit, E.E. (2010). Kadınların Mekânsal Davranışlarının Siyasal Niteliği,. Durudoğan, H., Gökşen, F., Oder, B. E., Yükseker, D. (Ed.), Türkiye'de Toplumsal Cinsiyet Çalışmaları içinde (s.179 197). İstanbul: Koç Üniversitesi Yayınları.

Arat, Y. (2010). Türkiye'de Modernleşme Projesi ve Kadınlar, Bozdoğan, S. ve Kasaba, R. (Ed.). Türkiye'de Modernleşme ve Ulusal Kimlik içinde. Erişim Tarihi:15 Kasım 2014. http://www.halkevleri.org.tr/diger/turkiyede-modernlesme-projesi-ve-kadinlar-yesim-arat.

Berktay, F. (2011). Politikanın Çağrısı. İstanbul: İstanbul Bilgi Üniversitesi Yayınları.

Bora, A.ve Günal, A. (2009). 90'larda Türkiye'de Feminizm. İstanbul: İletişim Yayınları.

Davidoff, L. (2002). Feminist Tarih Yazımında Sınıf ve Cinsiyet. Ateşer, Z. Somuncuoğlu, S. (Çev.). İstanbul: İletişim Yayınları.

Durkheim, E. (1992). Intihar. Ozankaya, Ö. (Çev.), Ankara: İmge Kitabevi.

Ecevit, Y. (2011). Toplumsal Cinsiyet Çalışmaları. Eskişehir:Anadolu Üniversitesi Yayınları.

Entwistle, J. (2012). Cinsiyet / Toplumsal Cinsiyet, Temel Sosyolojik Dikotomiler. Jenks, C. (Ed.), Şahin, İ. (Çev.), Ankara: Birleşik Yayınevi.

Ercins, G. (2013). Demokrasinin Bir Önkoşulu Olarak Kamusal Alan ve Türkiye'de Kamusal Alan Algısı. Cumhuriyet Üniversitesi İktisadi ve İdari Bilimler Dergisi, 14, 1, 297-313. Erişim Tarihi:20 Kasım 2014. http://dergi.cumhuriyet.edu.tr.

Giddens, A. (2008). Sosyoloji. İstanbul: Kırmızı Yayınları.

Göle, N. (2003). Kamusal Alan ve Sivil Toplum Üzerine. Sivil Toplum Dergisi, 1, 2. Erişim Tarihi: 16 Kasım 2014. http://www.siviltoplum.com.tr/?ynt=icerikdetay\&id=133.

Habermas, J. (2010). Kamusallı̆̆ın Yapısal Dönüşümü. Bora, T., Sancar, M. (Çev.) İstanbul: İletişim Yayınları. 
Kadının Statüsü Genel Müdürlüğü. (2014). Birleşmiş Milletler. Erişim Tarihi: 24 Mart 2014. http://kadininstatusu.aile.gov.tr/kaynak/ulusarasi-belgelerkuruluslar/uluslararasikuruluslar/birlesmis-milletler

Kubilay, Ç. (2014). İslami Muhafazakâr Kadın Yazarların Perspektifinden Kürtaj Tartışması: Eleştirel Bir Değerlendirme. Alternatif Politika, 6, 3, 387-421. Erişim Tarihi: 20 Aralık 2014. http://alternatifpolitika.com/page/docs/aralik2014/caglakubilay.pdf.

Parsons,T., Bales, F. (1964). Family, Socialization and Interaction Process. USA: The Free Press of Glencoe.

Ritzer, G. (2008). Modern Sosyoloji Kuramları. Hülür, H. (Çev.) Ankara: De ki yayıncılık.

Sallan Gül, S. (2014). Kadın, Aile ve Fıtrat Meselesi. Erişim Tarihi: 25 Aralık 2014. http://www.kazete.com.tr/makale_Kadin-aile-ve-fitrat-meselesi_1003.aspx.

Sancar, S. (2009). Erkeklik: İmkânsız İktidar. İstanbul: Metis Yayınları.

Slater, D. (2012). Kamusal / Özel, Temel Sosyolojik Dikotomiler. Jenks, C. (Ed.). Kenevir, F. (Çev.). Ankara: Birleşik Yayınevi. 